\title{
Influence of particle size on gas-adsorption
}

\section{experiments of shales: an example from a}

\section{Longmaxi Shale sample from the Sichuan Basin,}

\section{China}

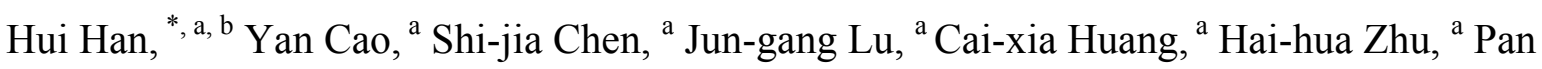
Zhan, ${ }^{\mathrm{a}}$ Yuan Gao ${ }^{\mathrm{c}}$

${ }^{a}$ School of Geoscience and Technology, Southwest Petroleum University, Chengdu, Sichuan 610500, P. R. China

${ }^{\mathrm{b}}$ Key Laboratory of Tectonics and Petroleum Resource (China University of Geosciences), Ministry of Education, Wuhan 430074, P. R. China

${ }^{c}$ Beijing Center for Physical and Chemical Analysis, Beijing 100089, P. R. China

ABSTRACT: To explore the optimum particle size range for low-pressure gas adsorption experiments of shales, a sample of the Longmaxi shale from the Sichuan Basin, China, was crushed into various particle sizes between 4 and $0.058 \mathrm{~mm}$. Low-pressure $\mathrm{CO}_{2}$ and $\mathrm{N}_{2}$ adsorption experiments were then performed on these crushed samples, and the pore volume, surface area, and pore size distribution (PSD) were determined from isotherms of gas adsorption. Variations in the volume of sorbed gas, pore volume, surface area, and PSD were recorded across the two series of experiments. In the $\mathrm{CO}_{2}$ adsorption experiments, in which 
particle size ranged from 4 to $0.83 \mathrm{~mm}$, sorbed gas volume, pore volume, and surface area increased with decreasing particle size. No obvious changes were found in sorbed volume, pore volume, surface area, or PSD for the samples with particle sizes from 0.83 to $0.058 \mathrm{~mm}$. In the $\mathrm{N}_{2}$ adsorption experiments, the sorbed gas volume and surface area increased with decreasing particle size in samples from 4 to $0.113 \mathrm{~mm}$, whereas no obvious variations were observed in the 0.113 to $0.058 \mathrm{~mm}$ samples. Similarly, pore volume and PSD showed clear changes with decreasing particle size for the 4 to $0.113 \mathrm{~mm}$ samples. The results show that $0.113 \mathrm{~mm}(130 \mathrm{mesh})$ is the optimum particle size for low-pressure $\mathrm{CO}_{2}$ and $\mathrm{N}_{2}$ adsorption experiments that seek to analyze the characteristics of shale reservoirs.

Key Words: Sichuan Basin; Longmaxi Shale; low-pressure gas adsorption; particle size; pore structure.

\section{INTRODUCTION}

Shale gas is an important unconventional gas resource that has been developed commercially in North America and China $[1,2]$. Due to its potential impact on gas storage and production, shale reservoir properties have been extensively studied. Scanning electric microscopy (SEM) [3-6], atomic-force microscopy (AFM) [7], mercury intrusion porosimetry (MIP) [8], computed tomography (CT) scanning ([9, 10], nuclear magnetic resonance (NMR) [11], low-pressure gas adsorption (LPGA) [12], and small angle X-ray and neutron scattering are all used to evaluate the reservoir potential of shales $[13,14]$. Compared with other methods, LPGA experiments are cost-effective and can provide quantitative information on the pore system in shale. Therefore, LPGA measurements are used extensively when studying the reservoir potential of shale. 
In LPGA experiments, shale samples need to be crushed before measurement; however, there is no standard particle size for the crushed shale. Although $0.25 \mathrm{~mm}$ (60 mesh) is most widely used [15-18], previous studies have also used $8 \mathrm{~mm}$ [19], 0.25-1.4mm [20], $0.38 \mathrm{~mm}$ [21], and $0.15 \mathrm{~mm}[22]$. Given that particle size can influence the pore volume, surface area, and PSD results obtained from LPGA experiments [23], it is important that a consistent particle size range be used to obtain reliable and comparable results of pore characteristics. Chen et al. [23] performed $\mathrm{CO}_{2}$ and $\mathrm{N}_{2}$ LPGA experiments on New Albany Shale samples with particle sizes of $4.75,0.83$, and $0.25 \mathrm{~mm}$, revealing that pore volume increases with decreasing particle size. This trend is ascribed to incomplete equilibration of the interior of larger shale particles during LPGA experiments [24]. Accordingly, Chen et al. [23] suggested a particle size below $0.83 \mathrm{~mm}$ for LPGA experiments. However, the particle size range used in their experiments was relatively narrow, and the trend of pore volume in shale samples with smaller particle sizes may be different from that observed for sizes of between 4.75 and 0.25 $\mathrm{mm}$. Therefore, the influence of particle size on LPGA experiments across a wider range of particle sizes needs to be explored.

In this study, a sample of Longmaxi Shale from the Sichuan Basin was crushed to particle sizes ranging from 4 to $0.058 \mathrm{~mm}$. Low-pressure gas adsorption experiments $\left(\mathrm{CO}_{2}\right.$ and $\left.\mathrm{N}_{2}\right)$ were then conducted with the aim of assessing the influence of particle size on shale microand meso-pore parameters such as pore volume, specific surface area, PSD, and sorbed gas volume. Finally, the optimal particle size ranges for shale samples used in low-pressure $\mathrm{CO}_{2}$ and $\mathrm{N}_{2}$ adsorption experiments are suggested.

\section{SAMPLE AND METHODS}

\subsection{Shale sample}


The Longmaxi Shale is the most important shale gas target in China [25]. In this study, a sample of the Lower Silurian Longmaxi Formation was collected from a shale gas well in the Sichuan Basin, Southwestern China. A CS-230 elemental analyzer (Leco Corporation, USA) was used to determine total organic carbon (TOC) content and a D/MAX 2500 X-ray diffractometer was used to measure mineral compositions. The reflectances of the solid bitumen were measured using a MPV-III microphotometer.

The results of the TOC measurements show that the selected sample is organic-rich and has a TOC content of $5.36 \mathrm{wt.} \%$ and a eq $R_{\mathrm{o}}$ value [26] of $1.59 \%$ (Table 1). Mineralogical analyses indicate the sample consists mainly of clay minerals (38.5 wt.\%) and quartz (35.3 wt.\%) with minor feldspar (9.1 wt.\%), dolomite (8.6 wt.\%), pyrite (7.4 wt.\%) and calcite (1.1 wt.\%). Mixed-layer illite/smectite and illite form the dominant clay minerals in the studied sample (Table 1).

\subsection{Low-pressure gas adsorption experiments}

The studied sample was crushed to $4,0.83,0.38,0.25,0.15,0.113,0.106,0.075$ and 0.058 $\mathrm{mm}$ (corresponding to 5,20,40,60,100,130,150, 200 and 250 mesh, respectively) with a pestle and mortar. The samples were then dried in an oven overnight at $110{ }^{\circ} \mathrm{C}$ and degassed under high vacuum $(<10 \mathrm{mmHg})$ for $12 \mathrm{~h}$ at $110^{\circ} \mathrm{C}[27]$.

Low-pressure $\mathrm{CO}_{2}$ and $\mathrm{N}_{2}$ adsorption experiments were performed using a Micromeritics ${ }^{\mathrm{R}}$ ASAP 2020 surface area analyzer. One to two grams of each of the crushed and degassed samples were exposed to $\mathrm{CO}_{2}$ and $\mathrm{N}_{2}$ at the temperatures of $0{ }^{\circ} \mathrm{C}$ and $-196.15{ }^{\circ} \mathrm{C}$, respectively. $\mathrm{CO}_{2}$ and $\mathrm{N}_{2}$ adsorption volumes were measured over the relative equilibrium adsorption pressure $\left(P / P_{o}\right)$ ranges of $0.0005-0.0300$ and $0.050-0.995$, respectively, where $P_{o}$ is the condensation pressure of $\mathrm{CO}_{2}$ or $\mathrm{N}_{2}$ under laboratory conditions, and $P$ is the actual gas pressure. $\mathrm{CO}_{2}$ molecule can access pores with diameter from 0.35 to $1.5 \mathrm{~nm}$, while $\mathrm{N}_{2}$ 
adsorption can reflect the pores with diameter between 1.2 and $100 \mathrm{~nm}$. Although the molecule diameter of $\mathrm{CO}_{2}(0.387 \mathrm{~nm})$ is larger than the $\mathrm{N}_{2}(0.315 \mathrm{~nm})$ [28], $\mathrm{CO}_{2}$ adsorption experiment was performed at $0{ }^{\circ} \mathrm{C}$, the corresponding temperature for $\mathrm{N}_{2}$ adsorption was $-196.15^{\circ} \mathrm{C}$. At the experimental temperatures, the thermal energy of $\mathrm{CO}_{2}$ molecule is greater than $\mathrm{N}_{2}$, which makes $\mathrm{CO}_{2}$ molecule can penetrate smaller pores [29]. Therefore, the pores measured using low-pressure $\mathrm{CO}_{2}$ adsorption experiment are smaller than low-pressure $\mathrm{N}_{2}$ adsorption experiment.

The pore volume, surface area, and pore size distribution (PSD) of each sample were then calculated using the density functional theory method (DFT) $[30,31]$. This method was chosen because it provides a more accurate description of the thermodynamic properties of the gas in the pores [32]. For $\mathrm{N}_{2}$ adsorption, the adsorption branches of the isotherms were used.

\section{RESULTS AND DISCUSSION}

\subsection{Low-pressure $\mathrm{CO}_{2}$ adsorption}

\subsubsection{Isotherms}

Figure 1 shows the low-pressure $\mathrm{CO}_{2}$ adsorption $\left(\mathrm{LPGA}-\mathrm{CO}_{2}\right)$ isotherms for each of the studied size grades. The isotherms are Type I, which indicates the studied sample is a microporous solid. The volume of sorbed $\mathrm{CO}_{2}$ increases with decreasing particle size from 4 to $0.83 \mathrm{~mm}$ (Figure 1a, b); however, no discernable variation in the volume of sorbed $\mathrm{CO}_{2}$ is observed in the 0.83 to $0.058 \mathrm{~mm}$ samples (Figure $1 \mathrm{~b}-\mathrm{i}$ ). Higher sorbed $\mathrm{CO}_{2}$ volumes in the 0.83 to $0.058 \mathrm{~mm}$ samples can be attributed to the higher degree of crushing of these samples. Figure 2 shows how crushing can expose pores trapped in larger particles. In the larger particle shown in Figure $2($ diameter $=4 \mathrm{~mm})$ there is an open pore and a closed pore. The 
$\mathrm{CO}_{2}$ can pass through the open pore but not the closed pore. In the smaller particle (diameter $=0.83 \mathrm{~mm}), \mathrm{CO}_{2}$ can pass through both pores, which are both open. The sorbed $\mathrm{CO}_{2}$ volume recorded for samples with a higher abundance of smaller particles $(\leq 0.83 \mathrm{~mm})$ is therefore greater than for the sample containing larger particles $(\geq 4 \mathrm{~mm})$.

\subsubsection{Pore volume and surface area}

The pore volumes obtained from the LPGA- $\mathrm{CO}_{2}$ experiments vary from 0.0034 to $0.0055 \mathrm{~cm}^{3} / \mathrm{g}$ (Table 2). Surface area results calculated from the $\mathrm{LPGA}-\mathrm{CO}_{2}$ data vary from 9.99 to $16.85 \mathrm{~m}^{2} / \mathrm{g}$ (Table 2).

The relationship between particle size and each of calculated pore volume and surface area in the studied shale samples are shown in Figures 3. The patterns observed in pore volume and surface area across the particle size range considered here match those of the volume of sorbed $\mathrm{CO}_{2}$ recorded. LPGA-CO $\mathrm{CO}_{2}$ measurements show an increase in pore volume with decreasing particle size from 4 to $0.83 \mathrm{~mm}$, and only minor differences in pore volume between the 0.83 and $0.058 \mathrm{~mm}$ samples (Figure 3a).

The pattern for LPGA-CO $\mathrm{CO}_{2}$-calculated surface area follows that of $\mathrm{LPGA}-\mathrm{CO}_{2}$-calculated pore volume. Minor fluctuations in the volume of $\mathrm{CO}_{2}$ are seen for the 0.83 to $0.058 \mathrm{~mm}$ samples, which all appear to contain a higher surface area than the $4 \mathrm{~mm}$ sample (Figure $3 \mathrm{~b}$ ).

\subsubsection{Pore size distribution}

The pore size distribution (PSD) calculated for each sample using the $\mathrm{LPGA}-\mathrm{CO}_{2}$ data is shown in Figure 4 . For the $4 \mathrm{~mm}$ sample there are two major peaks at pore size diameters of 0.6 and $0.8 \mathrm{~nm}$ (Figure $4 \mathrm{a}$ ), whereas the $0.83-0.058 \mathrm{~mm}$ samples show three major peaks at pore diameters of $0.4,0.6$, and $0.8 \mathrm{~nm}$ (Figure $4 \mathrm{~b}-\mathrm{i}$ ). Note that the relative heights of these three major peaks are similar in all samples finer than $4 \mathrm{~mm}$, with the exception of the 0.83 
mm sample which appears to contain a more significant $0.6 \mathrm{~nm}$ peak. Analysis of the pore size distribution in these Longmaxi Shale samples indicates that as particle size decreases from 4 to $0.83 \mathrm{~mm}$, a peak representing a pore diameter $0.4 \mathrm{~nm}$ appears in all samples from 0.83 to $0.058 \mathrm{~mm}$. The magnitude of this peak increases as particle size decreases from 0.83 to $0.25 \mathrm{~mm}$, then remains relatively constant in samples with a particle size from 0.15 to $0.058 \mathrm{~mm}$ (Figure 4). The increase in the magnitude of this peak with decreasing particle size from 0.83 to $0.25 \mathrm{~mm}$ may result from the exposure of trapped pores as a consequence of intense crushing (Figure 2).

\subsubsection{Influence of particle size}

According to the results above, there are no significant changes in the volume of sorbed $\mathrm{CO}_{2}$, pore volume, surface area, or PSD in samples with particle sizes of 0.83 to $0.058 \mathrm{~mm}$. Our results indicate that for the Longmaxi Shale a particle size no coarser than $0.83 \mathrm{~mm}$ is adequate for $\mathrm{LPGA}-\mathrm{CO}_{2}$ experiment.

\subsection{Low-pressure $\mathrm{N}_{2}$ adsorption}

\subsubsection{Isotherms}

The low-pressure $\mathrm{N}_{2}$ adsorption (LPGA- $\mathrm{N}_{2}$ ) isotherms of the studied samples are shown in Figure 5. According to the Brunauer, Deming, Deming, and Teller classification [33], the LPGA-N $\mathrm{N}_{2}$ isotherms are Type II, indicating that multi-layer adsorption has occurred in the studied samples. The volume of sorbed $\mathrm{N}_{2}$ increases with decreasing particle size from 4 to $0.113 \mathrm{~mm}$ (Figure 5a-f). The $0.106 \mathrm{~mm}$ sample has lower adsorption than the $0.113 \mathrm{~mm}$ sample. And the $0.075 \mathrm{~mm}$ sample has higher adsorption than the 0.106 and $0.058 \mathrm{~mm}$ samples. There is no obvious variation in the volume of sorbed $\mathrm{N}_{2}$ for samples with a particle size between 0.113 and $0.058 \mathrm{~mm}$. All the studied samples show hysteresis loops of type $\mathrm{H}_{4}$ $[34,35]$, indicating the pores are slit-type. Note that the hysteresis loop of the $4 \mathrm{~mm}$ sample 
(Figure 5a) can be attributed to the adsorption of nitrogen in micropores [34]. The hysteresis loops in the LPGA- $\mathrm{N}_{2}$ experiments become tighter as particle size decreases from 4 to 0.058 $\mathrm{mm}$ (Figure 5). This trend is similar to that reported by Chen et al. [23], who attributed this phenomenon to the shorter distance needed for desorption to occur in samples containing smaller particles. Consequently, less gas is trapped in pores during desorption.

Noticeably, both the $\mathrm{N}_{2}$ and $\mathrm{CO}_{2}$ adsorption measurements show the same initial trend, with the volume of sorbed gas increasing as particle size decreases; however, this trend is observed over a boarder particle size range in the $\mathrm{N}_{2}$ experiments $(4-0.113 \mathrm{~mm})$ compared than in the $\mathrm{CO}_{2}$ analyses $(4-0.83 \mathrm{~mm})$. This difference may relate to the detection limits of the LPGA- $\mathrm{CO}_{2}$ and LPGA-N 2 experiments. Carbon dioxide adsorption has a lower detection limit $(0.35 \mathrm{~nm})$ than nitrogen adsorption $(1.2 \mathrm{~nm})[36,37]$; in effect, $\mathrm{CO}_{2}$ can enter into smaller pore throats than $\mathrm{N}_{2}$. This is illustrated in Figure 6. For samples with a particle size of $4 \mathrm{~mm}$, the pore throat labeled ' $\mathrm{a}$ ' in Figure 6 is open to both $\mathrm{CO}_{2}$ and $\mathrm{N}_{2}$, whereas that labeled 'b' is closed. When the particle size decreases to $0.83 \mathrm{~mm}$, pore throat ' $\mathrm{a}$ ' is still open to $\mathrm{CO}_{2}$ and $\mathrm{N}_{2}$; however, pore throat ' $\mathrm{b}$ ' is now wide enough for $\mathrm{CO}_{2}$ to enter but not $\mathrm{N}_{2}$. For a particle size of $0.38 \mathrm{~mm}$, pore throats ' $a$ ' and ' $b$ ' are wide enough to be detected during LPGA- $\mathrm{CO}_{2}$ and LPGA-N $\mathrm{N}_{2}$ experiments.

\subsubsection{Pore volume and surface area}

Pore volume calculations from the LPGA-N $\mathrm{N}_{2}$ measurements range from 0.0076 and $0.0258 \mathrm{~cm}^{3} / \mathrm{g}$ (Table 2). The surface areas obtained from the LPGA-N $\mathrm{N}_{2}$ data range from 10.43 to $22.52 \mathrm{~m}^{2} / \mathrm{g}$ (Table 2).

LPGA-N $\mathrm{N}_{2}$ measurements indicate an increase in pore volume with decreasing particle size from 4 to $0.113 \mathrm{~mm}$, there is no obvious variation in LPGA-N $\mathrm{N}_{2}$-calculated pore volume for samples with a particle size between 0.113 and $0.058 \mathrm{~mm}$ (Figure 7a). LPGA-N 2 
measurements show an increase in surface area as particle size decreases from 4 to $0.113 \mathrm{~mm}$, but then a slight decrease in surface area from 0.113 to $0.058 \mathrm{~mm}$ (Figure $7 \mathrm{~b}$ ).

The surface area is calculated by dividing the area by the mass of the sample. It is assumed that the total pore volume is constant; consequently, the smaller the pore size, the larger the surface area. The observed trend in the LPGA-N $\mathrm{N}_{2}$ surface area values for the 4 to $0.113 \mathrm{~mm}$ samples therefore represents an increase in the number of open pores contributing to the overall pore volume as particle size decreases. In contrast, more big pores are open for detection in samples with particle sizes from 0.113 to $0.058 \mathrm{~mm}$. This explanation is supported by the relationships between surface area and pore volume (Figure 8). Initially, the surface area increases as pore volume increases, but then remains constant as pore volume continues to increase. This suggests that the increase in pore volume results from contributions from bigger pores that would have little impact on surface area.

\subsubsection{Pore size distribution}

The PSD calculated for each sample using the LPGA-N $\mathrm{N}_{2}$ data is shown in Figure 9. The $4 \mathrm{~mm}$ sample has a wide peak at $2-5 \mathrm{~nm}$ (Figure $9 \mathrm{a}$ ). The 0.83 to $0.058 \mathrm{~mm}$ samples show two major peaks at 2 and 3-5 $\mathrm{nm}$ (Figure $6 \mathrm{~b}-\mathrm{i}$ ). In these finer samples the magnitude of the $2 \mathrm{~nm}$ peak appears to decrease with decreasing particle size from 0.38 to $0.058 \mathrm{~mm}$.

The pore size distribution shows a peak at $2 \mathrm{~nm}$ and another between 3 and $5 \mathrm{~nm}$, both of which increase as the particle size decreases from 4 to $0.38 \mathrm{~mm}$ (Figure 9). This increase is likely to be related to the size of pores that can be detected in $\mathrm{N}_{2}$ adsorption (Figure 6). The height of the $2 \mathrm{~nm}$ peak decreases as particle size decreases from 0.38 to $0.058 \mathrm{~mm}$, indicating a decrease in the abundance of pores of $<2 \mathrm{~nm}$ in size.

\subsubsection{Influence of particle size}


According to the results in section 3.2, $\mathrm{LPGA}-\mathrm{N}_{2}$-obtained sorbed gas volume, pore volume, surface area, and PSD show no significant differences between the 0.113 and $0.058 \mathrm{~mm}$ samples. For the shale samples with particle sizes coarser than $0.113 \mathrm{~mm}$, these parameters mentioned above varied significantly. It can be attributed to that the $\mathrm{N}_{2}$ can't penetrate all the pores in the shale samples. The abundance of pores that $\mathrm{N}_{2}$ penetrate increased with the decreasing particle size in samples from 4 to $0.113 \mathrm{~mm}$. When the particle size decreased to $0.113 \mathrm{~mm}$, the $\mathrm{N}_{2}$ can detect almost all pores in samples. For the samples with sizes from 0.113 to $0.058 \mathrm{~mm}$, the abundance of pores detected using $\mathrm{N}_{2}$ adsorption experiments have no obvious variation, the corresponding parameters of pore characteristics are close to in-situ shales. These findings indicate that for the examination of pore systems in shale material using LPGA-N 2 , a particle size of $<0.113 \mathrm{~mm}$ is most suitable. Of course, only the pores connected with each other can be detected by low-pressure gas adsorption experiments. Some researchers argued that artificial pores and fractures in shale samples may be created during grounding [38]. However, the adsorption equilibration time of crushed samples is much less than bulk samples [24, 39]. Crushing and sieving have no significant influence on the microporosity $(<100 \mathrm{~nm})$ of shales [23].

Overall, as $\mathrm{N}_{2}$ adsorption experiments are typically used in conjunction with $\mathrm{CO}_{2}$ experiments, a particle size of $0.113 \mathrm{~mm}$ (130 mesh) is suggested for shale samples used in both low-pressure $\mathrm{CO}_{2}$ and $\mathrm{N}_{2}$ adsorption experiments.

\subsection{Uncertainties}

The present results suggest that shale samples with a particle size of $<0.83 \mathrm{~mm}(20 \mathrm{~mm})$ and $<0.113 \mathrm{~mm}(0.113 \mathrm{~mm})$ are used for LPGA-CO $\mathrm{CO}_{2}$ and LPGA-N $\mathrm{N}_{2}$ experiments, respectively. However, some small variations in the pore volume, surface area, and PSD have been observed in samples that match the above criteria. These small variations may relate to the 
heterogeneity of the Longmaxi Shale used in this study. It is probable that different samples, each with its own particle size, also had different organic matter and mineral compositions, and different pore structure. For example, Tinni et al. [40] reported different surface areas measured in samples with particle sizes of $0.07 \mathrm{~mm}(\sim 200 \mathrm{mesh})$ and $0.7 \mathrm{~mm}(\sim 24 \mathrm{mesh})$ from the same shale. This variation was attributed to differences in the abundance of organic matter. In addition, crushing may induce fractures and experimental error may arise when using the LPGA procedure [41]. It is emphasized that the particle size range suggested in this study for both LPGA-CO $\mathrm{CO}_{2}$ and LPGA-N $\mathrm{N}_{2}$ experiments was attained from an investigation involving just one shale sample (i.e., a sample of the Longmaxi Formation). Therefore, the applicability of the suggested particle sizes for other shales needs to be verified.

\section{CONCLUSIONS}

To assess the optimum particle size for shale samples used in low-pressure gas $\left(\mathrm{CO}_{2}\right.$ and $\left.\mathrm{N}_{2}\right)$ adsorption experiments, a Longmaxi Shale sample was ground into a range of particle sizes from 4 to $0.058 \mathrm{~mm}$. LPGA- $\mathrm{CO}_{2}$ and LPGA-N $\mathrm{N}_{2}$ experiments were then performed on the crushed samples.

In the LPGA- $\mathrm{CO}_{2}$ experiments, the volume of sorbed $\mathrm{CO}_{2}$, pore volume, and surface area increased as particle size decreased from 4 to $0.83 \mathrm{~mm}$. Noticeably, PSD data show a larger peak at a pore diameter of $0.4 \mathrm{~nm}$ in samples with a particle size smaller than $0.83 \mathrm{~mm}$. For the 0.38 to $0.058 \mathrm{~mm}$ samples, no significant changes in sorbed volume, pore volume, surface area, or PSD were observed. Accordingly, it is suggested that shale samples with a particle size below $0.83 \mathrm{~mm}$ are most suitable for $\mathrm{LPGA}-\mathrm{CO}_{2}$ experiments.

In the LPGA- $\mathrm{N}_{2}$ experiments the volume of sorbed $\mathrm{N}_{2}$ and calculated surface area increased as particle size decreased from 4 to $0.113 \mathrm{~mm}$; however, no obvious differences were observed in the 0.113 to $0.058 \mathrm{~mm}$ samples. Pore volume and PSD show a noticeable change 
as particle size decreases from 4 to $0.113 \mathrm{~mm}$; however, the change observed between the 0.113 and $0.058 \mathrm{~mm}$ samples is much less pronounced. Therefore, we suggest that shale samples with a particle size of $<0.113 \mathrm{~mm}$ are most suitable for LPGA-N $\mathrm{N}_{2}$ experiments. As the reservoir potential of shale samples is usually measured using both low-pressure $\mathrm{CO}_{2}$ and $\mathrm{N}_{2}$ adsorption experiments, a particle size of $0.113 \mathrm{~mm}$ (130 mesh) is suggested for all low-pressure adsorption experiments. However, it is worth noting that the heterogeneity typically exhibited by any given shale could result in error being introduced during sample preparation and analysis, and this would influence the reproducibility of LPGA results.

\section{AUTHOR INFORMATION}

\section{Corresponding Author}

*Tel.: +86 18302815786. E-mail: hanhuigeology@163.com.

\section{ACKNOWLEDGMENTS}

This project was funded by the National Science Foundation of China (41502144), the Young Scholars Development Fund of Southwest Petroleum University (SWPU) (201499010088), the Fund of Education Department of Sichuan Province (16ZA0075), the Fund of Key Laboratory of Tectonics and Petroleum Resources (TPR-2015-06), and the Sichuan Province University Scientific Innovation Team Construction Project (USITCP).

\section{REFERENCES}

[1] Jarvie D. M., Hill R. J., Ruble T. E., Pollastro R. M. Unconventional shale-gas systems: the Mississippian Barnett shale of north-central Texas as one model for thermogenic shale-gas assessment. AAPG Bull. 2007; 91(4) : 475-99.

[2] Guo T. L., Zhang H. R. Formation and enrichment mode of Jiaoshiba shale gas field, Sichuan basin. Petrol. Explor. Dev. 2014; 41(1): 31-40. 
[3] Loucks R. G., Reed R. M., Ruppel S. C., Jarvie D. M. Morphology, genesis, and distribution of nanometer-scale pores in siliceous mudstones of the Mississippian Barnett Shale. J. Sediment. Res. 2009; 79: 848-61.

[4] Milliken K. L., Rudnicki M., Awwiller D. N., Zhang T. Organic matter-hosted pore system, Marcellus Formation (Devonian), Pennsylvania. AAPG Bull. 2013; 97(2):177-200.

[5] Wang M., Wilkins R. W. T., Song G. Q., Zhang L. Y., Xu X. Y., Li Z., Chen G. H. Geochemical and geological characteristics of the Es $3^{\mathrm{L}}$ lacustrine shale in the Bonan sag, Bohai Bay basin, China. Int. J. Coal Geol. 2015; 138: 16-29.

[6] Wang M., Sherwood N., Li Z. S., Lu S. F., Wang W. G., Huang A. H., Peng J., Lu K. Shale oil occurring between salt intervals in the Dongpu Depression, Bohai Bay basin, China. Int. J. Coal Geol. 2015; 152: 100-12.

[7] Javadpour F., Farshi M. M., Amrein M. Atomic-force microscopy: a new tool for gas-shale characterization. J. Can. Pet. Technol. 2012; 7: 236-43.

[8] Sondergeld C. H., Ambrose R. J., Rai C. S., Moncrieff J. Micro-structural studies of gas shales. SPE Unconventional Gas Conference, Pittsburgh, PA, 23-25 February, 2010.

[9] Sisk C., Walls J., Suhrer M. 3D visualization and classification of pore structure and pore filling in gas shales. SPE Annual Technical Conference and Exhibition, Florence, Italy, 19-22 September, 2010.

[10] Walls J. D., Diaz E., Cavanaugh T. Shale reservoir properties from digital rock physics. SPE/EAGE European Unconventional Resources Conference and Exhibition, Vienna, Austria, 20-22 March, 2012. 
[11] Tinni A., Odusina E., Hughes B., Sulucamain I., Sondergeld C., Rai C. NMR response of brine, oil, and methane in organic rich shales. SPE Unconventional Resources Conference, Woodlands, Texas; April 1-3, 2014.

[12] Clarkson C. R., Jensen J. L., Blasingame T. A. Reservoir engineering for unconventional gas reservoirs: what do we have to consider?. The society of petroleum engineers North American unconventional gas conference and exhibition, Woodlands, Texas; June 12-16, 2011.

[13] Mastalerz M., He L., Melnichenko Y. B. Rupp J. A. Porosity of coal and shale: insights from gas adsorption and SANS/USANS techniques. Energy Fuel 2012; 26: 5109-20.

[14] Clarkson C. R., Solano N., Bustin R. M., Chalmers G. R. L., He L, Melnichenko A. P., Radliński A. P., Blach T. P. Pore structure characterization of North American shale gas reservoirs using USANS/SANS, gas adsorption, and mercury intrusion. Fuel 2013; 103: 606-16.

[15] Chalmers G. R., Bustin R. M., Power I. M. Characterization of gas shale pore systems by porosimetry, pycnometry, surface area, and field emission scanning electron microscopy/transmission electron microscopy image analyses: examples from the Barnett, Woodford, Hynesville, Marcellus, and Doig units. AAPG Bull. 2012; 96: 1099-1119.

[16] Li J. J., Yin J. X., Zhang Y. N., Lu S. F., Wang W. M., Li J. B., Chen F. W., Meng Y. L. A comparison of experimental methods for describing shale pore features-a case study in the bohai bay basin of eastern China. Int. J. Coal Geol. 2015; 152: 39-49.

[17] Wang M., Xue H. T., Tian S. S., Wilkins R. W. T., Wang Z. W. Fractal characteristics of Upper Cretaceous lacustrine shale from the Songliao basin, NE China. Mar. Petrol. Geol. 2015; 67: 144-53. 
[18] Mastalerz M., Schimmelmann A., Drobniak A., Chen Y. Porosity of Devonian and Mississippian New Albany shale across a maturation gradient: insights from organic petrology, gas adsorption, and mercury intrusion. AAPG Bull. 2013; 97: 1621-43.

[19] Schmitt M., Fernandes C. P., da Cunha Neto J. A. B., Wolf F. G., dos Santos V. S. S. Characterization of pore systems in seal rocks using nitrogen gas adsorption combined with mercury injection capillary pressure techniques. Mar. Petrol. Geol. 2013; 39: 139-49.

[20] Mohammad M. L., Rezaee R., Saeedi A., Al Hinai A. Evaluation of pore size spectrum of gas shale reservoirs using low pressure nitrogen adsorption, gas expansion and mercury porosimetry: a case study from the Perth and Canning basins, western Australia. J. Petrol. Sci. Eng. 2013; 112: 7-16.

[21] Kuila U. Prasad M., Derkowski A., McCarty D. K. Compositional controls on mudrock pore-size distribution: an example from Niobrara Formation. SPE Annual Technical Conference and Exhibition, San Antonio, Texas; October 8-10, 2012.

[22] Cao T. T., Song Z. G., Wang S. B., Cao X. X., Li Y., Xia J. Characterizing the pore structure in the Silurian and Permian shales of the Sichuan basin, China. Mar. Petrol. Geol. 2015; 61: 140-50.

[23] Chen Y. Y., Wei L., Mastalerz M., Schimmelmann A. The effect of analytical particle size on gas adsorption porosimetry of shale. Int. J. Coal Geol. 2015; 138: 103-12.

[24] Clarkson C. R., Bustin R. M. The effect of pore structure and gas pressure upon the transport properties of coal: a laboratory and modeling study. 1. Isotherms and pore volume distributions. Fuel 1999; 78: 1333-44. 
[25] Zou C. N., Dong D. Z., Wang S. J., Li J. Z., Li X. J., Wang Y. M. Li D. H., Cheng K. M. Geological characteristics and resource potential of shale gas in China. Petrol. Explor. Dev. 2010; 37: 641-53.

[26] Jacob H. Classification, structure, genesis and practical importance of natural solid oil bitumen (“migrabitumen”). Int. J. Coal Geol. 1989; 11: 65-79.

[27] Tian H., Pan L., Xiao X. M., Wilkins R. W. T., Meng Z. P., Huang B. J. A preliminary study on the pore characterization of Lower Silurian black shales in the Chuandong Thrust Fold Belt, Southwestern China using low pressure $\mathrm{N}_{2}$ adsorption and FE-SEM methods. Mar. Petrol. Geol. 2013; 48: 8-19.

[28] Sondergeld C. H., Newsham K. E., Comisky J. T., Rice M. C., Rai C. S. Petrophysical considerations in evaluating and producing shale gas resources. SPE Unconventional Gas Conference, Pittsburgh, PA, 23-25 February, 2010.

[29] Chalmers G. R. L., Bustin R. M. On the effects of petrographic composition on coalbed methane sorption. Int. J. Coal Geol. 2007; 69: 288-304.

[30] Do D. D., Do H. D. Pore characterization of carbonaceous materials by DFT and GCMC simulations: a review. Adsorpt. Sci. Technol. 2003; 21(5): 389-423.

[31] Zhang Z., Yang Z. Theoretical and practical discussion of measurement accuracy for physisorption with micro- and mesoporous materials. Chin. J. Catal. 2013; 34: 1797—1810.

[32] Neimark A.V., Lin Y., Ravikovitch P.I., Thommes M. Quenched solid density functional theory and pore size analysis of micro-mesoporous carbons. Carbon 2009; 47: 1617-28.

[33] Brunauer S., Deming L. S., Deming W. E., Teller E. On a theory of the van der Waals adsorption of gases. J. Am. Chem. Soc. 1940; 62(7): 1723-1732. 
[34] Gregg S. J., Sing K. S. W. Adsorption, surface area, and porosity. 1982, New York: Academic Press, 303p.

[35] Sing K. S. Reporting physisorption data for gas/solid systems with special reference to the determination of surface area and porosity. Pure and Appl. Chem. 1985; 57: 603-19.

[36] Chalmers G. R. L., Bustin R. M. Porosity and pore size distribution of deeply-buried fine-grained rocks: influence of diagenetic and metamorphic process on shale reservoir quality and exploration. J. Unconv. Oil Gas 2015; 12: 134-42.

[37] Unsworth J. F., Fowler C. S., Jones L. F. Moisture in coal: 2. Maceral effects on pore structure. Fuel 1989; 68: 18-26.

[38] Black D. Factors affecting the drainage of gas from coal and methods to improve drainage effectiveness. PhD Thesis, University of Wollongong, Wollongong, Australia; 2012.

[39] Gamson P., Beamish B. Coal type, microstructure and gas flow behavior of Bowen Basin coals. Symposium on Coalbed Methane Research and Development in Australia, Coalseam Gas Research Institute-James Cook University, Townsville, 19-21 November, 1992.

[40] Tinni A., Songdergeld C., Rai C. Particle size effect on porosity and specific surface area measurements of shales. International Symposium of the Society of Core Analysts, Avignon, France; September 8-11, 2014.

[41] Boudriche L., Chamayou A., Calvet R., Hamdi B., Balrd H. Influence of different dry milling processes on the properties of an attapulgite clay, contribution of inverse gas chromatography. Powder Technol. 2014; 254: 352-63. 
Table 1. TOC content and mineral composition of the studied sample.

\begin{tabular}{|c|c|c|c|c|c|c|c|c|c|c|c|c|}
\hline \multirow{2}{*}{$\begin{array}{l}\text { Depth } \\
\text { (m) }\end{array}$} & \multirow{2}{*}{$\begin{array}{c}\text { TOC } \\
\text { (wt. \%) }\end{array}$} & \multirow{2}{*}{$\mathrm{eq} R_{\mathrm{o}}{ }^{\mathrm{a}}(\%)$} & \multicolumn{6}{|c|}{ Mineral composition (wt.\%) } & \multicolumn{4}{|c|}{ Clay mineral composition (wt.\%) } \\
\hline & & & Clay & Quartz & Feldspar & Calcite & Dolomite & Pyrite & $\mathrm{I} / \mathrm{S}$ & Illite & Kaolinite & Chlorite \\
\hline 3112.06 & 5.36 & 1.59 & 38.5 & 35.3 & 9.1 & 1.1 & 8.6 & 7.4 & 49 & 33 & 3 & 15 \\
\hline
\end{tabular}

${ }^{\mathrm{a}} \mathrm{Eq} R_{\mathrm{o}}$ is calculated according to the equation established by Jacob [26]. I/S: mixed-layer illite/smectite. 
Table 2. Pore volume and surface area for the studied samples.

\begin{tabular}{ccccc}
\hline \multirow{2}{*}{ Particle size $(\mathrm{mm})$} & \multicolumn{2}{l}{ Pore volume $\left(\mathrm{cm}^{3} / \mathrm{g}\right)$} & \multicolumn{2}{c}{ Surface area $\left(\mathrm{m}^{2} / \mathrm{g}\right)$} \\
\cline { 2 - 5 } & $\mathrm{CO}_{2}$ & $\mathrm{~N}_{2}$ & $\mathrm{CO}_{2}$ & $\mathrm{~N}_{2}$ \\
\hline 4 & 0.0034 & 0.0076 & 9.99 & 10.43 \\
0.83 & 0.0047 & 0.0100 & 14.34 & 17.12 \\
0.38 & 0.0047 & 0.0112 & 14.41 & 19.04 \\
0.25 & 0.0046 & 0.0124 & 14.46 & 21.01 \\
0.15 & 0.0042 & 0.0169 & 13.31 & 21.81 \\
0.113 & 0.0055 & 0.0258 & 16.85 & 22.52 \\
0.106 & 0.0050 & 0.0210 & 16.07 & 22.36 \\
0.075 & 0.0045 & 0.0241 & 14.45 & 21.12 \\
0.058 & 0.0044 & 0.0248 & 14.60 & 20.84
\end{tabular}

$\mathrm{CO}_{2}$ : data obtained from $\mathrm{CO}_{2}$ adsorption experiments; $\mathrm{N}_{2}$ : data obtained from $\mathrm{N}_{2}$ adsorption experiments.

The data in Table 2 includes the whole pore size ranges that $\mathrm{CO}_{2}$ and $\mathrm{N}_{2}$ detect. 

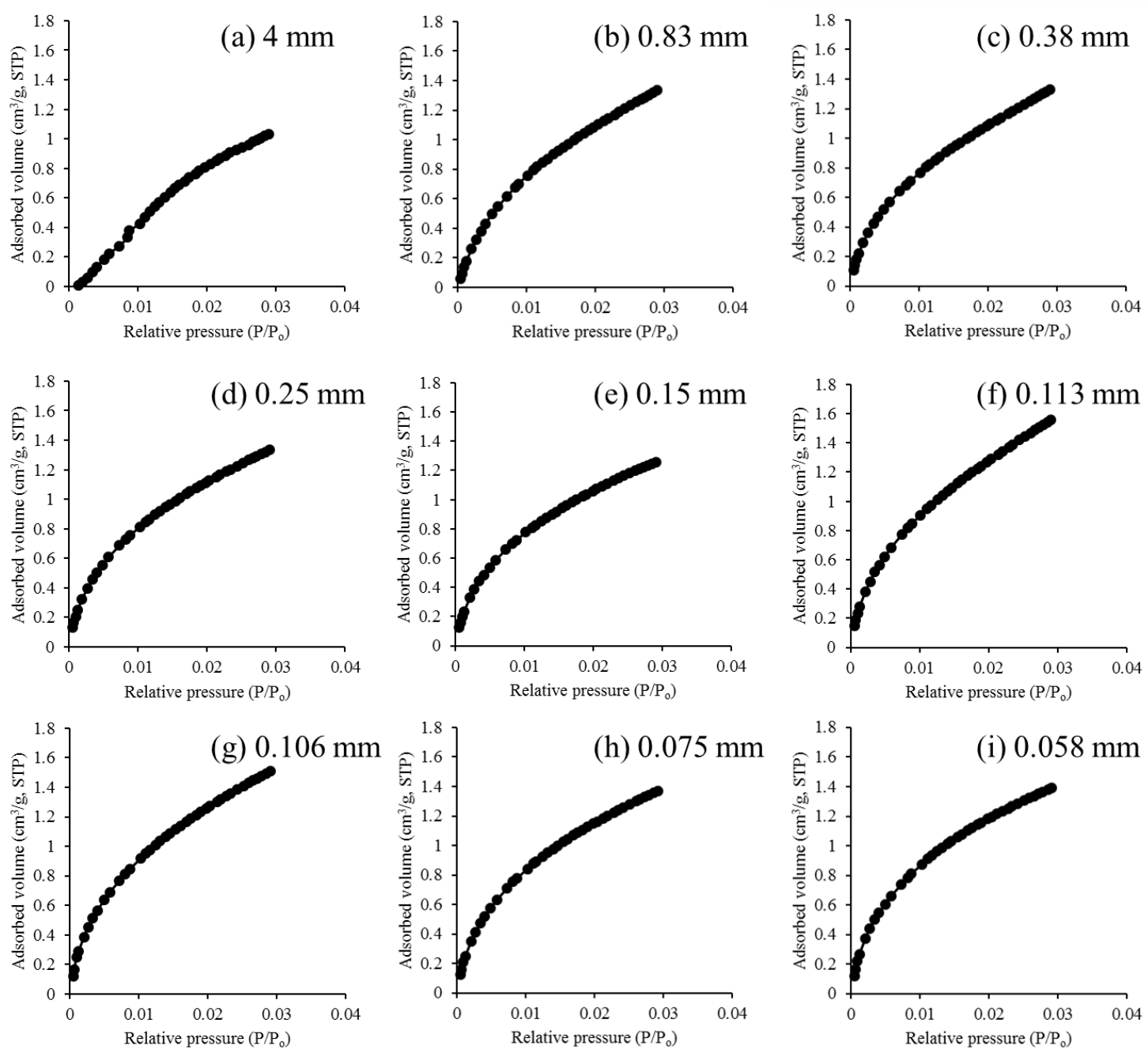

Figure 1. Low-pressure $\mathrm{CO}_{2}$ adsorption isotherms for the studied samples. 

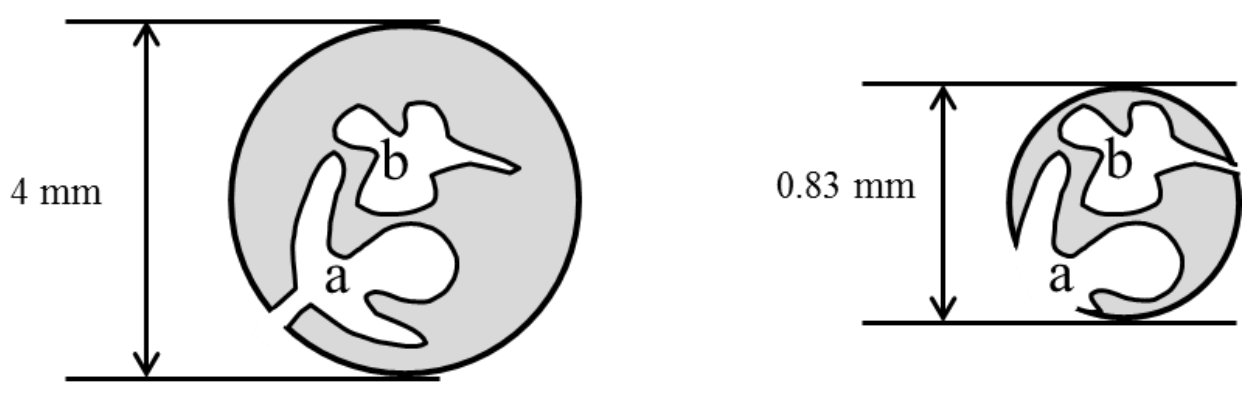

Figure 2. Influence of sample particle size on low-pressure $\mathrm{CO}_{2}$ adsorption experiments. 

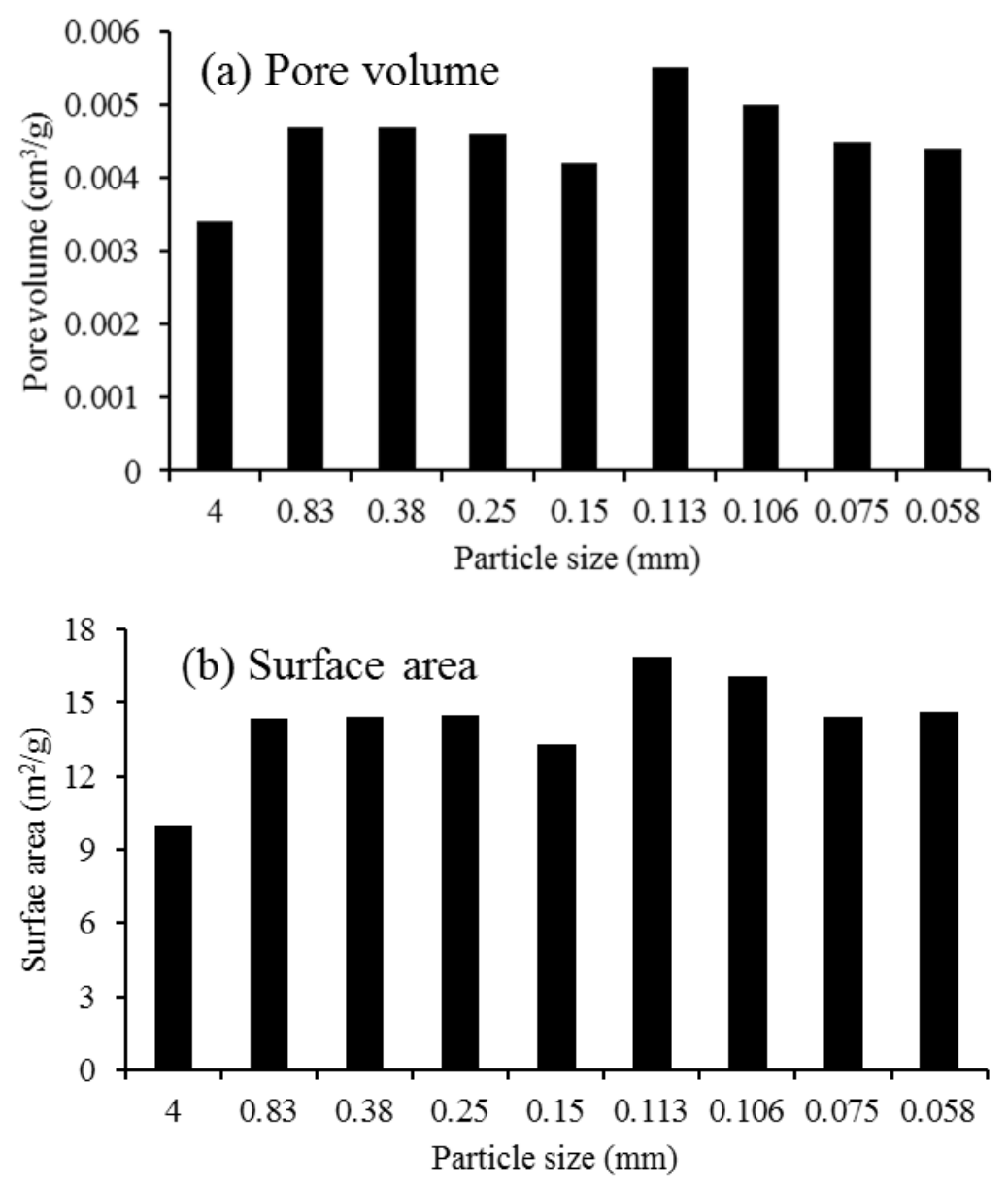

Figure 3. Pore volume and surface area data obtained from low-pressure $\mathrm{CO}_{2}$ adsorption data for the studied samples. 

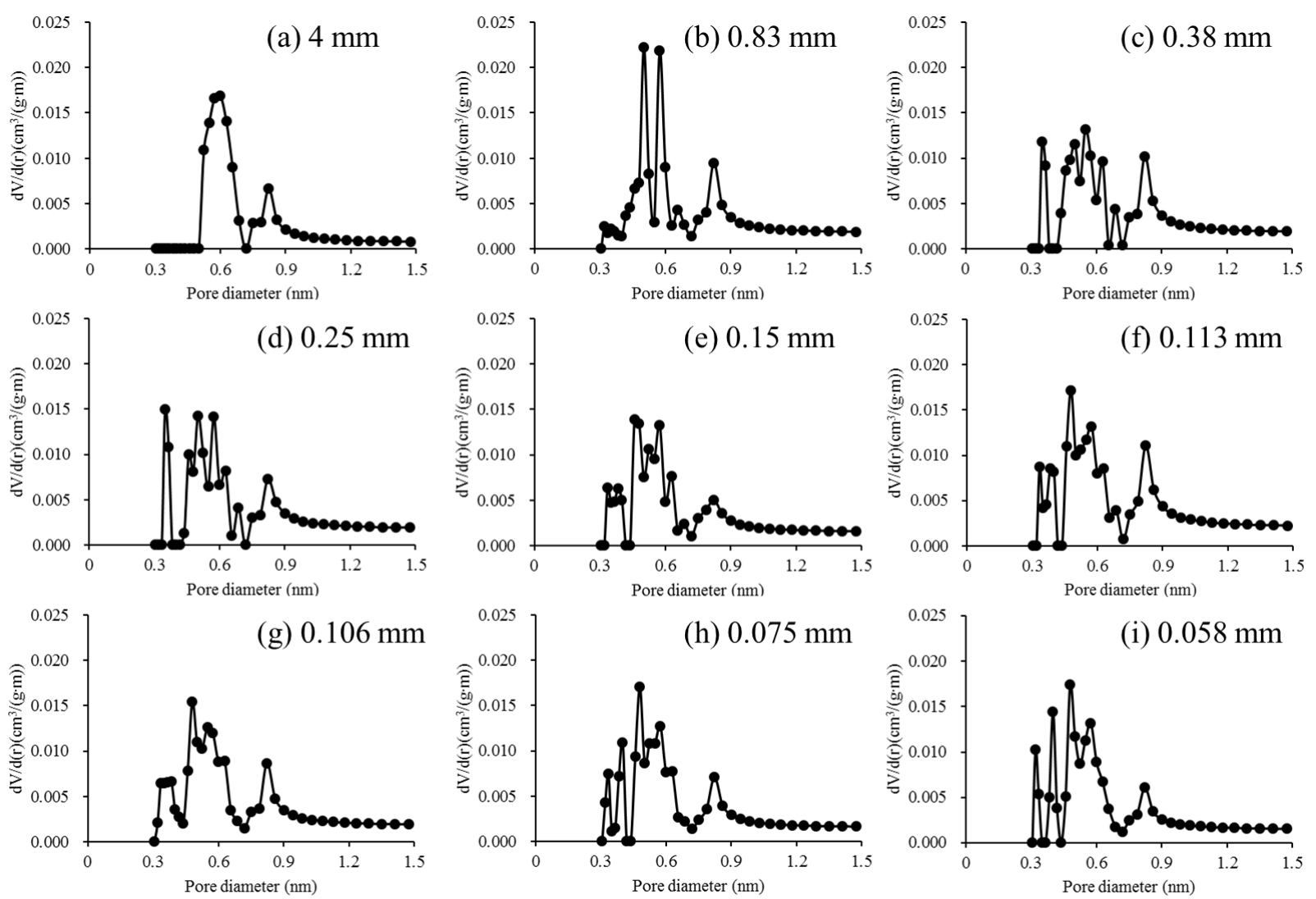

Figure 4. Pore size distributions obtained from low-pressure $\mathrm{CO}_{2}$ adsorption data for the studied samples. 

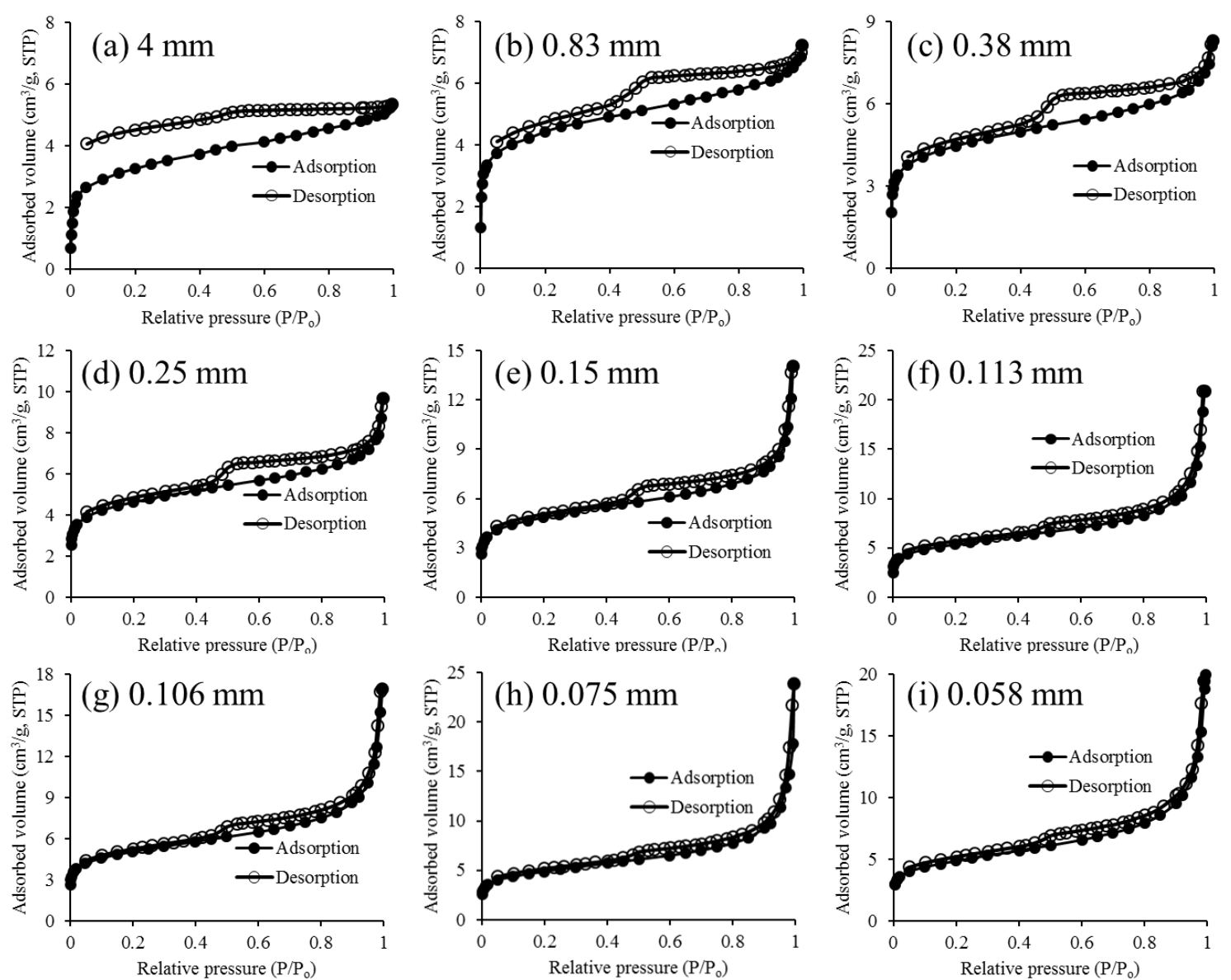

Figure 5. Low-pressure $\mathrm{N}_{2}$ adsorption isotherms for the studied samples. 

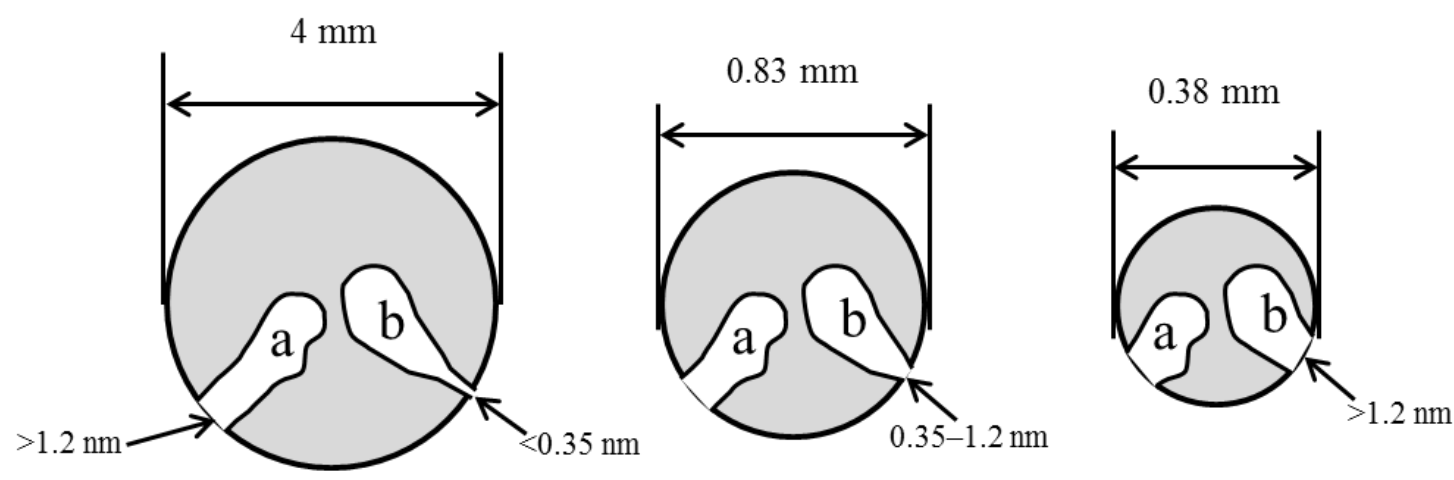

Figure 6. Influence of sample particle size on low-pressure gas $\left(\mathrm{CO}_{2}\right.$ and $\left.\mathrm{N}_{2}\right)$ adsorption experiments. 

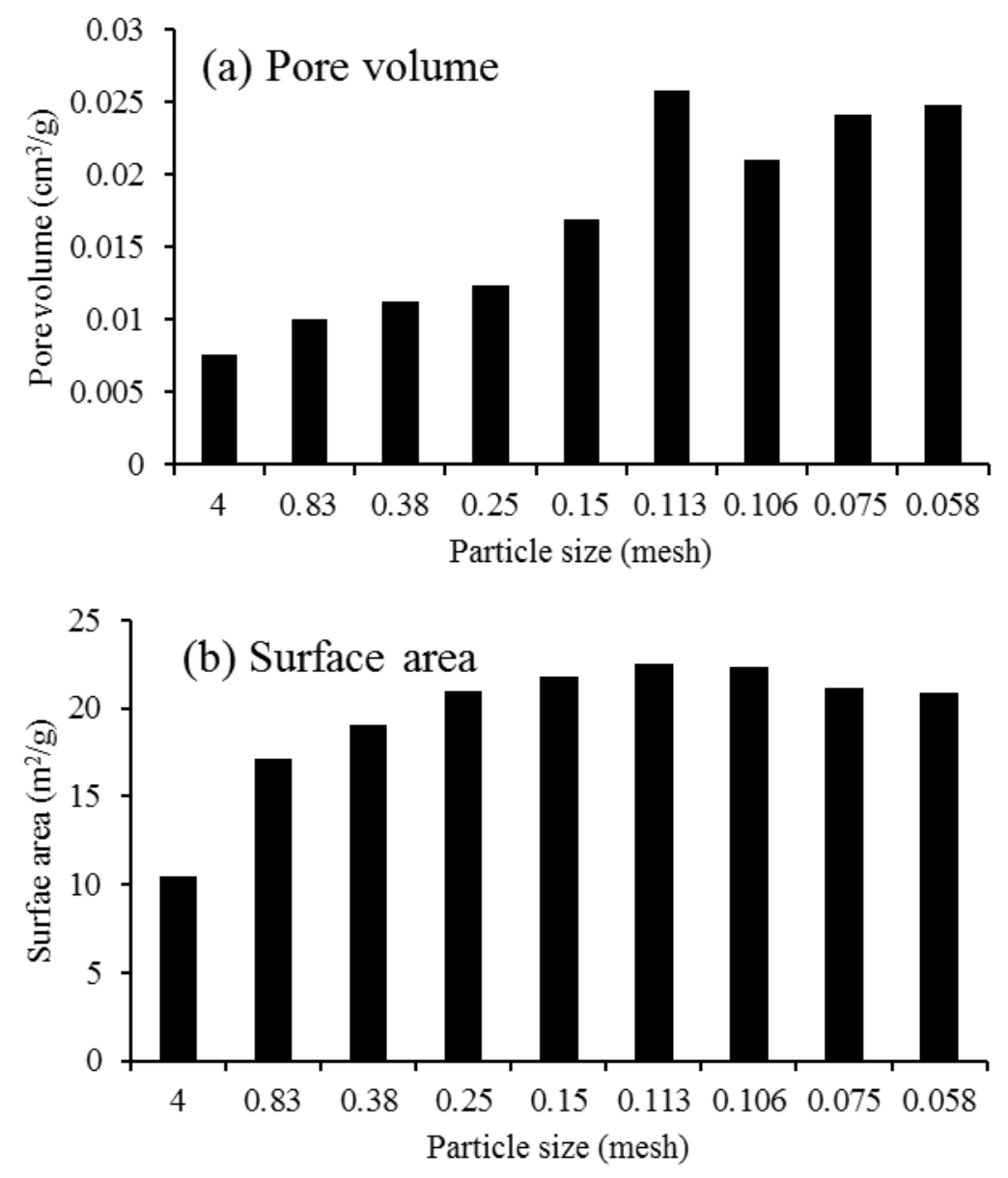

Figure 7. Pore volume and surface area data obtained from low-pressure $\mathrm{N}_{2}$ adsorption data for the studied samples. 


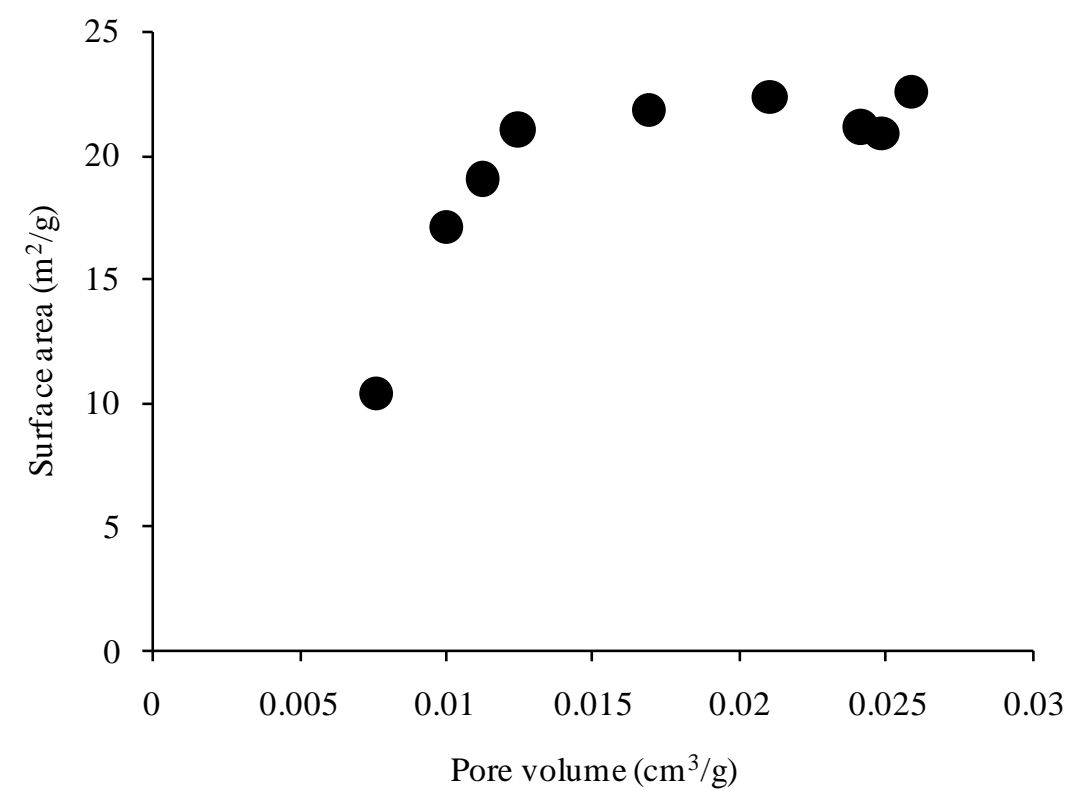

Figure 8. Relationships between surface area and pore volume obtained from low-pressure $\mathrm{N}_{2}$ adsorption data for the studied samples. 

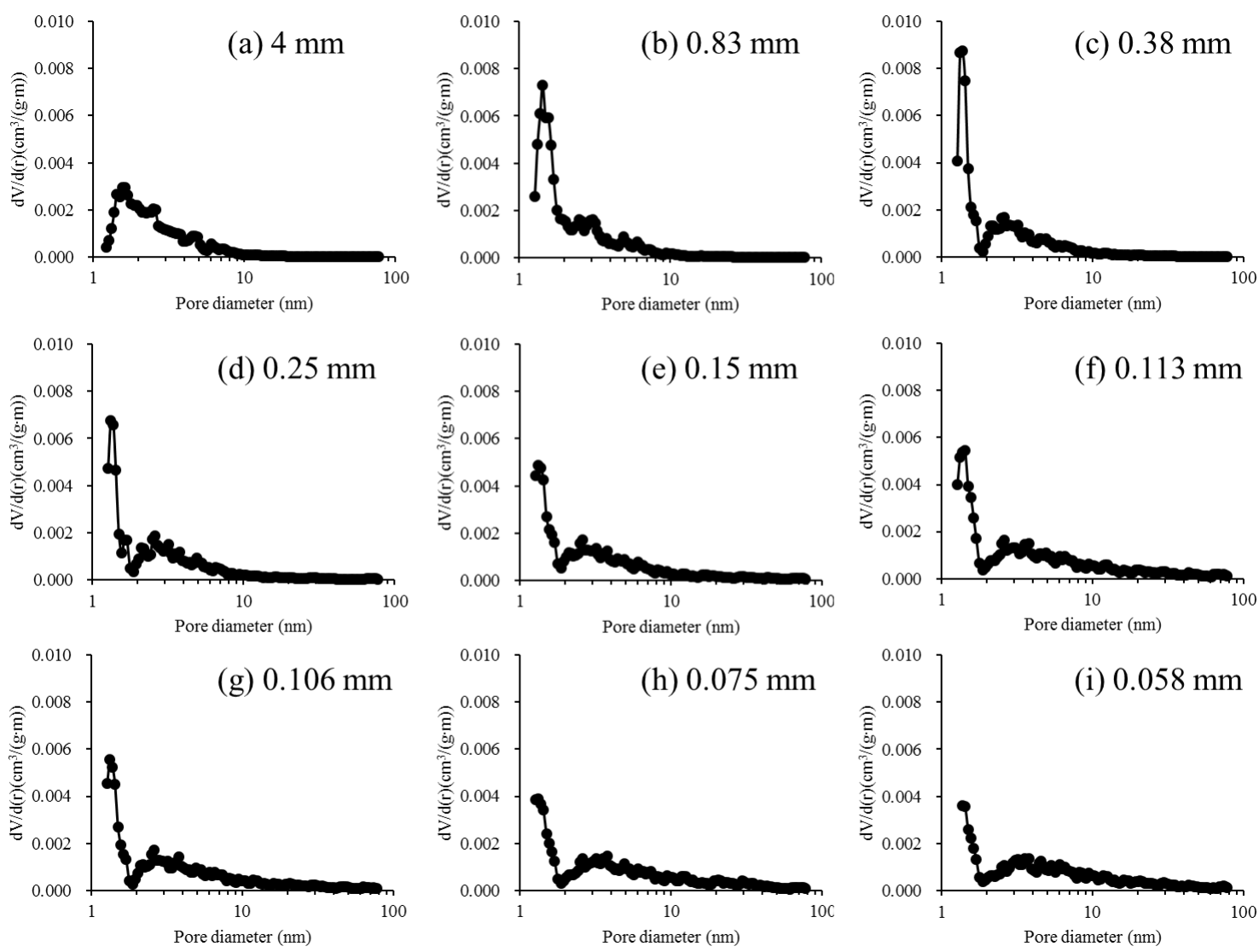

Figure 9. Pore size distributions obtained from low-pressure $\mathrm{N}_{2}$ adsorption data for the studied samples. 